\title{
THE LEARNING OUTCOMES APPROACH IN FORMAL SECOND CHANCE EDUCATION: CASE OF LATVIA
}

\section{Dmitrijs Kul̦ šs}

University of Latvia, Faculty of Education, Psychology and Art

\begin{abstract}
This paper focusses on the use of a learning outcomes approach based on the empirical quantitative data gathered from 82 teachers of the second chance education institutions in Latvia. For this purpose, built on the academic literature and policy documents' review the author attempts to define the learning outcomes approach. The analysis of the empirical data presents elements of the use of the approach in the setting of a second chance education in Latvia and provides initial findings to support more coherent learning outcome based formal second chance education.
\end{abstract}

Keywords: learning outcomes approach, formal second chance education.

\section{Introduction}

There is an extensive evidence in the literature typifying persons who fail to complete a school as considerably disadvantaged (Black, Polidano, \& Tseng, 2012; Traag, 2011). A debate towards reducing the share of early leavers from education (defined by the Eurostat as 'a person aged 18 to 24 who has finished no more than a lower secondary education and is 1 not involved in further education or training') is on-going among scholars and policy makers in Europe and outside. The EU-28 average share of early leavers from education Europe's 2020 strategy indicator - has auspiciously decreased from $16.9 \%$ in 2002 to $12.0 \%$ in 2013 . Figure 1 depicts a Europe's 'struggle' towards its goal of less than $10 \%$ of early leavers from education by 2020 . Despite a positive trend there is still a potential for combating the early leaving from education.

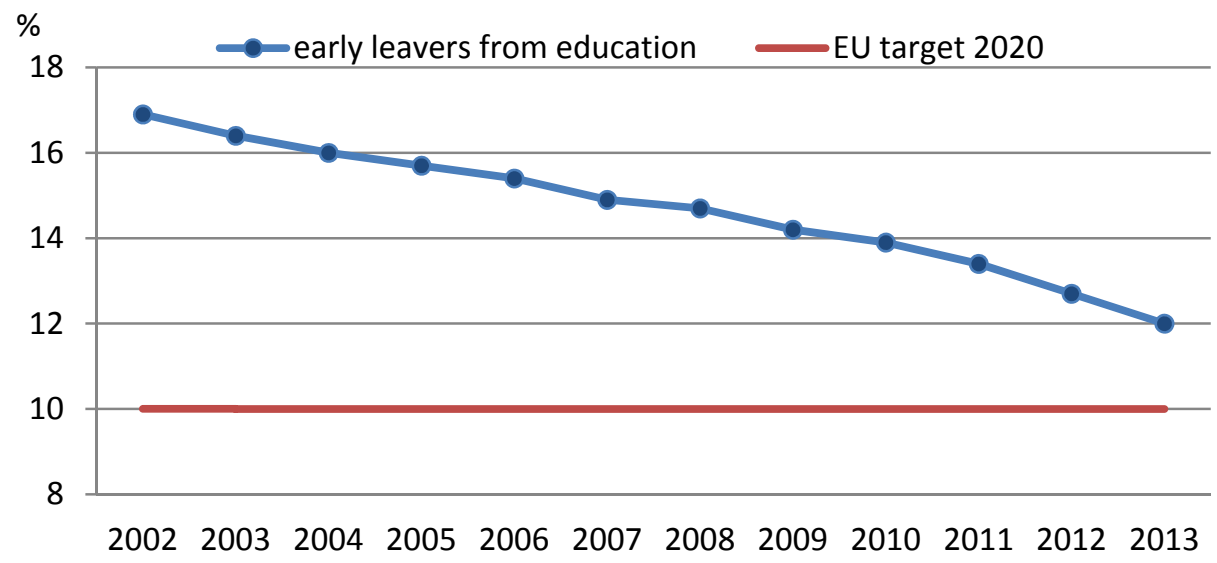

Source: Eurostat, 2014

Figure 1 Early leavers from education and training in the EU-28 (2002-13) 
While possessing a starting point that is EU equal in 2002 (16.9) a share of early leavers in Latvia has decreased more rapidly in 2011-13 and reached 10.5\%. The range of underlying endogenous (educational) and exogenous (socioeconomic, cultural, etc.) factors that cause students to stop learning prematurely is substantial (Vallejo \& Dooly, 2013), thus, is the need to address them. Argued whether positive or disadvantageous (Allais, 2012) learning outcomes are among influential endogenous factors.

Learning outcomes have recently entered and strengthened its positions in the field of education. In the discourse of important and influential elements for a paradigm change in education (Thomas, 2007) and educational practice (Lipman, 2003) very little is actually known about the use of learning outcomes in particular settings, especially in general education.

'Across Europe, the post-compulsory phase of general education is the part of the education system that has been least influenced by reforming ideas about learning outcomes' (CEDEFOP, 2011)

Once introduced from the policy domain learning outcomes are expected to improve the quality of education systems, including pedagogical aspects (Bruner, 1966) as part of lifelong learning (Field, 2006) that encompasses approach of valuing every learning (outcome) throughout our lives and has implications for the purpose and process of learning (Crowther \& Sutherland, 2007; Usher \& Edwards, 2007; Field, 2005).

A lifelong learning cannot limit itself to a non-formal or informal learning only. There seem to be a need to fundamentally transform initial education systems or schooling to be open for all (Longworth, 2003). This also implies to adults who return to education process after dropping out from school followed by a period of out-of-school activities.

The emphasis of the paper is on the use of the learning outcomes approach by teachers in the second chance educational setting. It aims at revealing some aspects of application using a quantitative analysis of empirical data from the Latvian second chance general education schools (Latvian: vakarskolas). Further it provides initial findings to support more coherent learning outcome based formal second chance education.

Methodology. A desk research method to define the learning outcomes approach has been employed and a quantitative analysis has been used to make conclusions on the empirical data (Cohen, Manion, \& Morrison, 2007). A questionnaire adapted from Trigwell et al.. (1999) has been translated into Latvian and distributed electronically to teachers from evening schools in Latvia. The SPSS software has been used to draw the conclusions on the qualitative data. Limitations. A sample from 76 teachers' responds from all schools is required to ensure a confidence level of $95 \%$ to ensure representative results (Cohen et al., 2007). Despite the sufficient sample size, it does not cover all schools. Therefore the sample does not allow to make generalizations. However the data gives a good notion of the state of play. 


\section{Learning outcomes approach}

There is no consensus among scholars what are the origins of learning outcomes concept. It may be loosely traced to Watson (1858-1958) and Skinner (19041990) behavioural school of psychological thought and Pavlof (1849-1936) dog conditioning experiments (Adam, 2004). The main idea connected to learning outcomes in behavioural school was clear measurement of results of learning measurable outcomes. In Europe learning outcomes as we see them now are associated with rapid expansion of secondary and tertiary education in the mid20th century (Hussey \& Smith, 2002) that increased dramatically education public expenditure and consequently caused the need for more accountability of learning. Learning outcomes serve as accountability element for policy makers and society so 'that the community in general and governments in particular can be in a better position to monitor what happens in [...] education' (Kennedy, 2009). Hussey \& Smith (2002) state laconically: 'What was implicit must be explicit and the subjective intuitions of educators must be replaced with objective, measurable criteria'. Accountability is also one of the rationales of Bloom's taxonomy where he describes learning outcomes as 'an attempt to build a taxonomy of educational objectives [...] to provide for classification of the goals of [...] educational system' (Bloom, 1956).

In light of 'politicization' of research (Roger, 2002) in order to use a rooted-inthe-policy-domain definition of a learning outcomes approach in the analysis of empirical data we attempt to exert the reverse: aggregate theoretical knowledge relevant to the policy definition. Learning outcomes phenomena and learning outcomes approach can be construed from various contexts: policy, education, pedagogy. In each context the answer to the question 'what is the learning outcomes approach?' would retain diverse interpretations, often contrasting. Table 1 presents some selected contexts to be considered in this paper.

Table 1

Various contexts relevant to the learning outcomes approach

\begin{tabular}{l|l|l}
\hline Education & Policy & Pedagogy \\
\hline Learning outcomes approach & Learning outcomes as & Learning outcomes approach \\
(Field, 2006; Schuller \& & policy instrument (May & within pedagogical context \\
Watson, 2009, CEDEFOP, & \& Winter, 2009) & (Barr \& Tagg, 1995; Bloom, \\
$2011 ;$ Nicoll, 2006) & & $\begin{array}{l}\text { Mesia, \& Krathwohl, 1964; } \\
\text { Driscoll \& Wood, 2007) }\end{array}$ \\
\hline
\end{tabular}

There is no common approach in using learning outcomes (CEDEFOP, 2011). Adam (2004) argues that learning outcomes is a widely used term in Europe although comprehension of its meaning remains questioned. Education policy has become a successful instrument of promoting learning outcomes notably for the past two decades (Strain \& Field, 1997). At the micro level or practical implementation of learning outcomes in education systems, consideration of 
curriculum design, teaching, learning, assessment, and quality assurance (Adam, 2004; Battersby, 1999) is of great importance. Learning outcomes are vital to provide clarity of who, how, what and when teaches, learns, and assesses. This also raises the fundamental question of approaches to education and of emphasis from the teacher-oriented education to student-centred one, where learning is seen 'as personal process affected by the embeddedness of the learner in social collectivities' (Nygaard, Højlt, \& Hermansen, 2008).

With no contradiction to the previous statement, learning outcomes may also be described at three different scales 1) transnational, 2) national and 3) local (Adam, 2004). The local level is represented by the institutions - implementing bodies of educational programme that provide a learner opportunity to acquire knowledge, skills and competences. Expressed in measurable units learning outcomes are serving as a tool or instrument that clarifies the outcomes of the educational programme for the learner. It helps teachers to provide relevant support to students using relevant methods. It assists school to identify the overlaps between subjects in curriculum and helps assessment to be objective rather than comparative. At the national level learning outcomes may provide relevant information to policy makers of return on investment. In other words to understand and take informed decisions of public spending to education. Although this neo-liberal view lies within hundred years of traditions since Adam Smith's economic theory (Klees, 2008), it may be argued to be dominating for justification of use of learning outcomes at the national level all over the world particularly during past two-three decades. The lead motive from the national level is considered as to be reframing education systems to utilise outcomes-based approach rather than to finance inputs.

Learning outcomes approach is a broad concept that stands in theories from behaviourism and similar educational initiatives such as mastery learning (Airasian \& Block, 1971), behavioural objectives (Mager, 1984), and competency based approaches (Argüelles \& Gonczi, 2000) to progressivism or constructivism aspects of learning and teaching, e.g. the idea of 'student focused learning' (Bruner, 1966; Kennedy, 2009; Spady, 1994). Within the mentioned broad limits of understanding the term, high level of precaution needs to be maintained in interpretation of learning outcomes due to a loose connection to the context in which they are observed that Bjørnavold (CEDEFOP, 2009) describes as a 'set of keys loosely linked to the context'.

Many other definitions of learning outcomes may be traced: from behaviourist 'products of the learning process' or transferable commodity (Gagné \& Driscoll, 1988) and 'product of cognitive, skill-based and affective learning' (European Parliament, 2008); to Battersby (1999) argument of learning outcomes and their ability to influence the teaching and learning and conceptual shift towards making learning more meaningful and effective for students quantitative and qualitative learning outcomes Shuell (1986). Even critics of learning outcomes admit that products are a necessary part of education: 'For 
the sake of objectivity we needed to be able to specify observable products of the activities of the educators: i.e. learning outcomes' (Hussey \& Smith, 2002). Once stated, objectives are expected to be transformed into outputs, while outputs affect outcomes or performance over time.

We argue that communication or understanding of learning outcomes is still one of the major tasks to be reached. Presume we are facing two different situations. In one there is no or limited information for student about what is going to be acquired during the upcoming class - learning outcomes are not part of the process from the student perspective. In another situation student is informed about what learning outcomes are to be acquired after during learning. It is likely that different teaching and learning approaches will be used in two situations, meaning learning outcomes can influence teaching and learning. By underpinning influence of learning outcomes to teaching and learning we simultaneously question an emphasis of individual learner in educational process. This implies to the pedagogical aspects of educational process rather than result of learning itself. Central role of the learner here may also be reflected in perception of learning influenced by information received about what learning outcomes will be achieved in the end of learning. Tolhurst (2007) presents evidence of and argues that students with more sophisticated epistemological beliefs achieve higher results in their learning. Existing literature also indicates that complex epistemological beliefs are directly connected to and also result in improved learning outcomes (Andre \& Windshitl, 2003; Hofer \& Pintrich, 2002; Schraw, 2001).

Figure 2 presents a conceptualisation of learning outcomes approach in education. It shows main elements of learning outcomes (result and process) linked to understanding and communication as well as to curriculum, pedagogy and assessment. The learning outcomes approach encloses a result-oriented thinking, a shift from inputs to outcomes, a change in perception of learning, a balance between qualitative and quantitative outcomes, and a conceptual shift towards more meaningful learning and is interlinked to the main elements of learning outcomes though the abovementioned intermediaries.

For the purpose of this paper we define learning outcomes approach to education as a meaningful and learner-centred approach derived from the use of learning outcomes that influences curriculum, pedagogy and assessment and serves as communication, thinking-change and accountability instrument for policy makers, educational professionals and learners. 


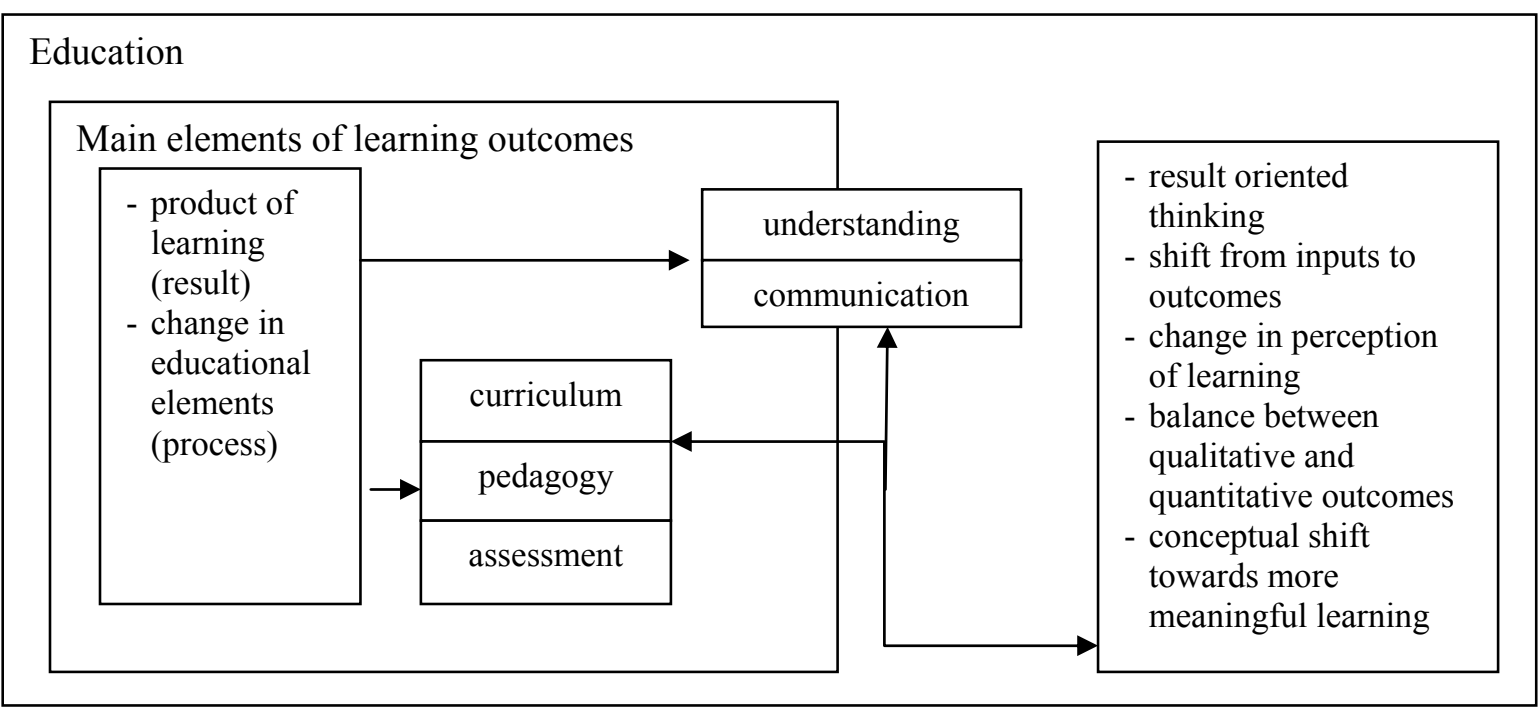

Figure 2 Conceptualisation of the learning outcomes approach

\section{Learning outcomes in the second chance education in Latvia}

The main objective of empirical data collection and analysis has been to discover whether the learning outcomes approach is a reality in the Latvian second chance education schools that employ a 'different teaching and counselling approach focusing on the individual's needs, wishes and abilities, and stimulating his or her active learning' (Linna \& Jansen, 2000) where adults or young adults are the main users (Kulıšs, 2012).

According to Knowles and Jarvis there are significant differences between adult learners and young learners (Merriam, Caffarella, \& Baumgartner, 2007) that can be roughly described in a way that adults are more self-directed, knowing why they learn, and ready to apply immediately acquired learning outcomes. Adapted to from Trigwell et al. (1999) teachers' questionnaire have been used containing eight information transmission / teacher-focused (ITTF) items and eight conceptual change/ student-focused (CCSF) items.

Based on the proposed definition of the learning outcomes approach and retaining limitations connected to it we suggest that the CCSF concept is helpful to describe the use of learning outcomes approach, while the ITTF concept may indicate to relevance to the approach to a much lesser degree or even provide of a notion of a non-use of learning outcomes approach.

A teacher survey was carried out from November 28, 2011 to December 12, 2011 using online survey service questionpro.com.

A request to fill in the translated into Latvian questionnaire was sent to 124 teachers from 21 evening schools in Latvia with total population of 634 teachers. From 84 surveys that were returned, 82 have been marked valid and have been included into the dataset for further analysis. On average seven minutes were spent to answer all questions which three minutes more than our 
initial estimate. Overall representation of subject groups have been as follows: math (14.6\%), languages (28.1\%), science (24.4\%), and other subjects (32.9\%). Some initial findings are presented in Figure 3. Teachers in all subjects language, mathematics and science - use dominantly the ITTF approach, where information transmission and teacher-focus are the main drivers. In teaching mathematics the difference is more explicit (-0.864) than in the science and language subject group. The science subject has less negative (non-use) sum of ITTF and CCSF factors $(-0.263)$ than the language and the math subjects. Other subjects appear to have a balance of the application of the CCSF and ITTF concepts in teaching.

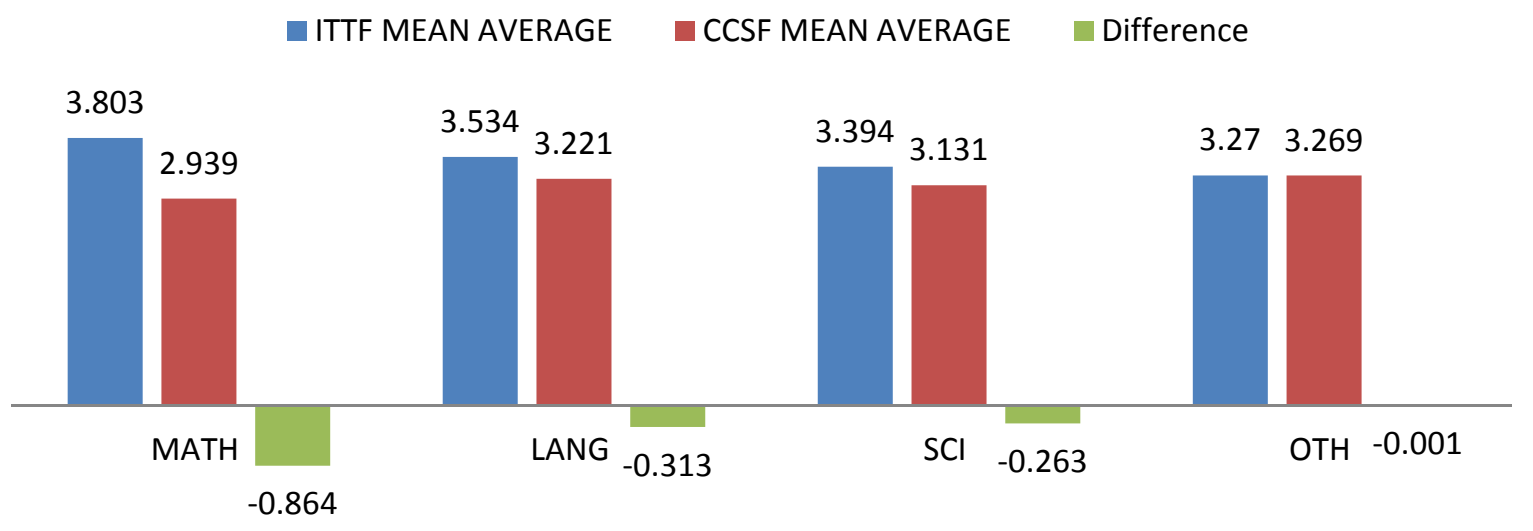

Figure 3 Indication of the use of learning outcomes approach by a study subject

An interpretation of the results indicate a non-use of learning outcomes approach. To understand the reasons behind we attempt to deconstruct the ITTF responds and to highlight the links (correlations) between the items.

Figure 4 exposes the links between teachers' tension to describe specific objectives of the subject relating to what the students have to know for formal assessment items; responsibility to know all the answers that students may pose; a wish to present as many facts during the lessons as possible; and a need to structure the subject to help students to pass the formal assessment.

There is also a link between a teachers' will to focus only on knowledge for formal assessment and a tension to teach, so students would have good notes as a result, but despite a strong correlation this case is less visible since one of its components has a little impact (mean).

We conclude from the analysis that in the evening schools - formal second chance education schools - in Latvia that preparation for formal assessment appears to be one of the major objectives of teacher in his/her view. It further links to teachers' perception of the need to be able to answer all the questions possible. By the teachers opinion there is nothing that he/she may not know. Another interlinked teachers' position is between describing objectives for formal assessment and 'fact shooting' as a main work instrument instead of discussions. This again leads to the need to be able to answer all the questions of 
the students. Presenting as many facts to students as possible also frames teachers work into the structure where help to the students to pass formal assessment is the main element. We may call it an 'exam framed knowledge' that represents the will to exclusively prepare for formal assessment and putting teaching efforts to serve this goal.

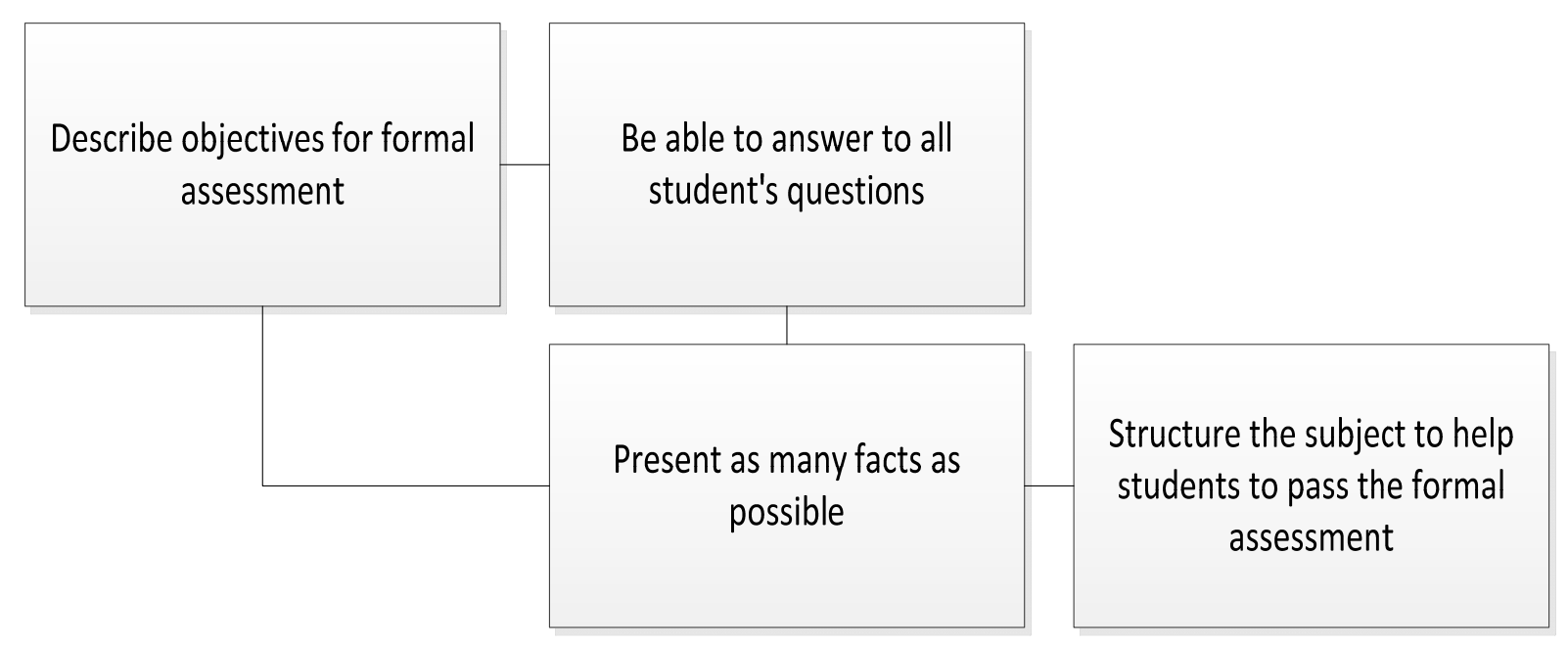

Figure 4 Links between the ITTF items

While the ITTF items provide us with evidence of interlinked barriers the CCSF items and ITTF-CCSF linked items with strong links may provide data on opportunities for the use of learning outcomes approach.

Figure 5 captures opportunities for a better use of learning outcomes approach. Analysis shows that teachers' view on the need to devote time questioning the ideas of students' links to the use of difficult examples to provoke a debate. The correlation is strong between the two elements ( $\mathrm{S} . r h o=0.491)$. However, teachers admit that in their view it is not very important to give these elements a frequent use (1.92-2.65) for questioning the ideas and (1.92-2.17) for the use of difficult examples to provoke a debate. Notably the language subject teachers in both cases use these elements more actively than mathematics and science teachers. Another opportunity has been revealed in the link $(\mathrm{S} . \mathrm{rho}=0.457)$ between questioning the ideas of students and allowing them to discuss their changing understanding of the subject. The math teachers are using this opportunity less (1.83) than the science (3.25) and the language teachers (3.04). 


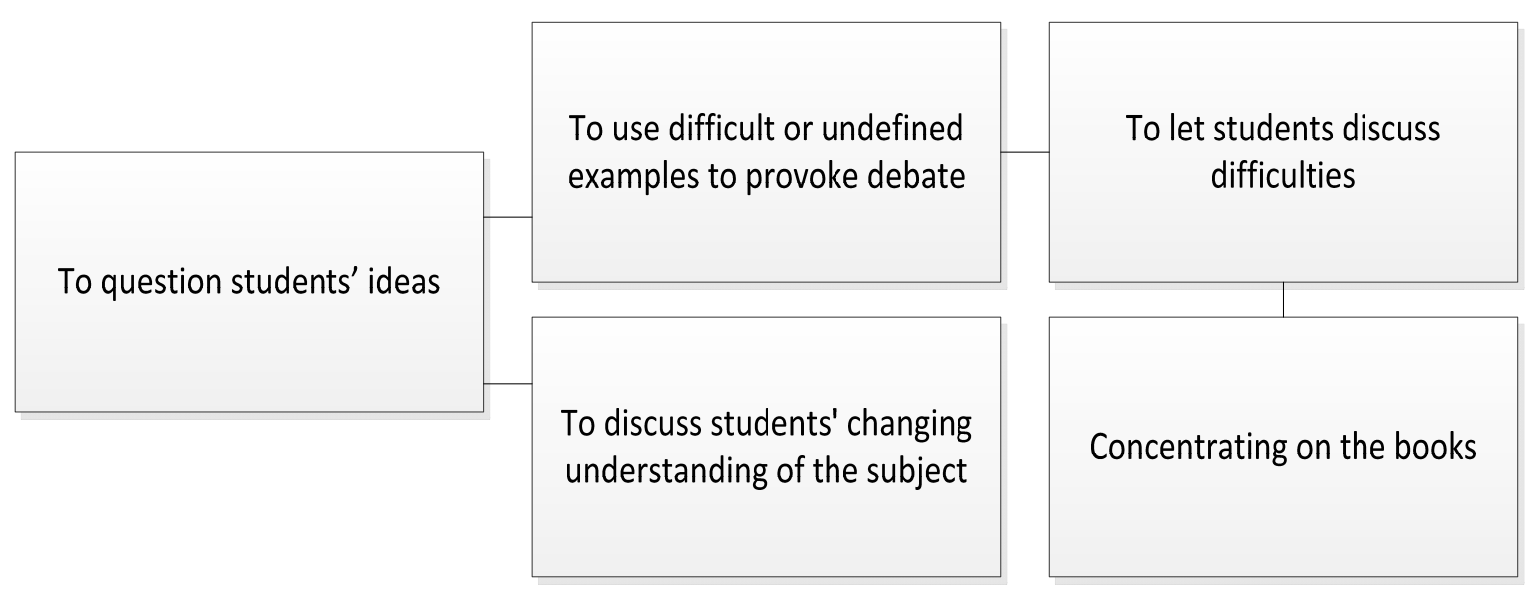

Figure 5 Links between ITTF items

The opportunity has been also defined and expressed in the link (S.rho=.400) between teachers letting students to discuss difficulties they encounter during the class and use of difficult examples by teachers to provoke a debate. None of these elements are used frequently in all three subjects and therefore the opportunity to improve exists in this area.

The link $(\mathrm{S} . r h o=0.445)$ also exists between teachers letting students to discuss difficulties they encounter during the class and concentrating mostly on the books (ITTF item). It is worth noting that this is the link between ITTF and CCSF items. We define this as better opportunity that links between one item group since there is an opportunity to raise use of learning outcomes approach through improving elements that are not directly connected to it or may be even in contrary to the idea of learning outcomes approach.

\section{Conclusions}

According to the analysis of the empirical data the use of learning outcomes approach in the second chance education schools in Latvia can be described as vague. Tradition of teaching primarily concentrates on students ability pass an examination and is overwhelming in all subjects. An 'exam framed knowledge' teaching is experienced by evening school teachers and represents the need to prepare for formal assessment only and putting teaching efforts to serve this goal. Student ideas are of no significant importance for teachers although teachers report they encourage students to restructure their existing knowledge in terms of the new way of thinking about the subject that they will develop. There is a strong link between a teachers' view on the need to devote a lot of time questioning the ideas of the students and to use difficult examples to provoke a debate. However these elements are not used very actively by teachers. Questioning the ideas of students and allowing them to discuss their changing understanding is linked but the math teachers are using this opportunity the less compare to the science and language subject teachers. There 
is a correlation between CCSF and ITTF items which may be translated as an opportunity to improve use of learning outcomes approach. Concentration on the books in the second chance education schools has a strong link with letting students to have an opportunity to discuss their difficulties during the class. There is a link between importance to present a lot of facts during the class in the evening schools and the view of teachers that the assessment should be an opportunity for students to reveal their changed conceptual understanding of the subject that reveals an opportunity to improve the use of learning outcomes approach through addressing more non-CCSF approach items.

\section{Acknowledgement:}

\section{This work has been supported by the European Social Fund within the project 'Support for doctoral studies at University of Latvia'}

\section{References}

1. Adam, S. (2004). Using learning outcomes: a consideration of the nature, role, application and implications for European education of employing "learning outcomes" at the local, national and international levels. Edinburgh: Scottish Executive.

2. Airasian, P.W., \& Block, J.H. (1971). Mastery learning: theory and practice. Edited by James H. Block. With selected papers by Peter W. Airasian, Benjamin S. Bloom [and] John B. Carroll. New York: Holt, Rinehart and Winston.

3. Allais, S. (2012). Claims vs. practicalities: lessons about using learning outcomes. Journal of Education and Work, 25(3), 331-354.

4. Andre, T., \& Windshitl, M. (2003). Interest, epistemological beliefs, and intentional conceptual change. In G. Sinatra, P. Pintrich, \& P. R. Mahwah (Eds.), Intentional conceptual change. NJ: Lawrence Erlbaum.

5. Argüelles, A., \& Gonczi, A. (2000). Competency based education and training: a world perspective. México: Editorial Limusa.

6. Barr, R., \& Tagg, J. (1995). From Teaching to Learning - A New Paradigm for Undergraduate Education. Change Magazine, (November/December).

7. Battersby, M. (1999). So, What's a Learning Outcome Anyway. Learning Outcomes and the Learning Paradigm. Department of Philosophy, Capilano College.

8. Black, D., Polidano, C., \& Tseng, Y.-P. (2012). The Re-engagement in Education of Early School Leavers*. Economic Papers: A Journal of Applied Economics and Policy, 31(2), 202-215. doi:10.1111/j.1759-3441.2011.00157.x

9. Bloom, B. S. (Ed.). (1956). Taxonomy of educational objectives: Book 1, Cognitive domain. New York: Longman.

10. Bloom, B. S., Mesia, B., \& Krathwohl, D. (1964). Taxonomy of Educational Objectives (Vols. 1-2). New York: David McKay Co Inc.

11. Bruner, J. S. (1966). Toward a theory of instruction. Cambridge, Mass.: Belknap Press of Harvard University.

12. CEDEFOP. (2009). The shift to learning outcomes. Policies and practices in Europe. Luxembourg: Office for Official Publications of the European Communities.

13. CEDEFOP. (2011). Using Learning Outcomes. Luxembourg: Publications Office of the European Union.

14. Cohen, L., Manion, L., Morrison, K. (2007). Research methods in education. Routledge. 
15. Crowther, J., \& Sutherland, P. (2007). Lifelong Learning: Concepts and Contexts. Routledge.

16. Driscoll, A., \& Wood, S. (2007). Developing Outcomes-Based Assessment for LearnerCentered Education: A Faculty Introduction. Stylus Publishing, LLC.

17. European Parliament. (2008). Recommendation of the European Parliament and of the Council on the establishment of the European qualifications framework for lifelong learning. Official Journal of the European Union Luxembourg: Publications Office, $\mathrm{C}(111)$.

18. Eurostat. (2014). Early leavers from education and training. Theme: Population and social conditions. Retrieved from

http://epp.eurostat.ec.europa.eu/tgm/table.do?tab=table\&init=1\&language $=$ en $\&$ pcode $=$ tsd sc410\&plugin $=0$

19. Field, J. (2005). Social Capital and Lifelong Learning. The Policy Press.

20. Field, J. (2006). Lifelong Learning and The New Educational Order. Trentham Books.

21. Gagné, R. M., \& Driscoll, M. P. (1988). Essentials of learning for instruction. Prentice Hall.

22. Hofer, B.K., \& Pintrich, P.R. (Eds.). (2002). Personal epistemology: the psychology of beliefs about knowledge and knowing. Mahwah, NJ: Lawrence Erlbaum Associates, Inc.

23. Hussey, T., \& Smith, P. (2002). The Trouble with Learning Outcomes. Active Learning in Higher Education, 2002(3), 220-233.

24. Kennedy, K. (2009). Outcomes based learning, concepts, issues and action. Retrieved from

www.ied.edu.hk.ez.statsbiblioteket.dk:2048/obl/files/OBLConcepts $\% 20$ Issues $\% 20$ and $\% 2$ 0Action_Kennedy.doc

25. Klees, S.J. (2008). A quarter century of neoliberal thinking in education: misleading analyses and failed policies. Globalisation, Societies and Education, 6(4), 311-348.

26. Kulšss, D. (2012). Pieaugušo formālā un neformālā izglītība, kā arī informālā mācīšanās kā mūžizglîtības principa ieviešanas elements. In K. Mārtinsone (Ed.), Pieaugušo izglìtība: rakstu krājums (RaKa.). Rīga.

27. Linna, E.-K., \& Jansen, J. (2000). Second Chance Schools: Teaching Methodologies. CESO. Retrieved from http://ec.europa.eu/education/archive/2chance/reppeda.pdf

28. Lipman, M. (2003). Thinking in Education. Cambridge University Press.

29. Longworth, N. (2003). Lifelong Learning in Action: Transforming Education in the 21st Century. Routledge.

30. Mager, R. (1984). Preparing instructional objectives. S.1.: Lake Pub.

31. May, P.J., \& Winter, S.C. (2009). Politicians, Managers, and Street-Level Bureaucrats: Influences on Policy Implementation. Journal of Public Administration Research and Theory, 19(3), 453-476. doi:10.1093/jopart/mum030

32. Merriam, S.B., Caffarella, R.S., \& Baumgartner, L. (2007). Learning in adulthood: a comprehensive guide. San Francisco: Jossey-Bass.

33. Nicoll, K. (2006). Flexibility \& Lifelong Learning: Policy, Discourse, Politics. Taylor \& Francis.

34. Nygaard, C., Højlt, T., \& Hermansen, M. (2008). Learning-Based Curriculum Development. Higher Education, 55(1), 33-50.

35. Roger, P.A. (2002). Policy, Politics and Perspective: The Scientific Community Must Distinguish Analysis from Advocacy. Nature, (416).

36. Schraw, G. (2001). Current Themes and Future Directions in Epistemological Research: A Commentary. Educational Psychology Review, 13(4), 451-464.

37. Schuller, T., \& Watson, D. (2009). Learning through Life: Inquiry into the Future for Lifelong Learning. National Institute of Adult Continuing Education. 
38. Shuell, T.J. (1986). Cognitive Conceptions of Learning. Review of Educational Research, $56(4), 411-436$.

39. Spady, W. . (1994). Outcome-based education: critical issues and answers. Arlington, Va.: American Association of School Administrators.

40. Strain, M., \& Field, J. (1997). On the myth of the learning society. British Journal of Educational Studies, 45(2), 141-55.

41. Thomas, G. (2007). Education and Theory: Strangers in Paradigms. McGraw-Hill International.

42. Tolhurst, D. (2007). The influence of learning environments on students' epistemological beliefs and learning outcomes. Teaching in Higher Education, 12(2), 219-233. doi:10.1080/13562510701191992

43. Trigwell, K., Prosser, M., \& Waterhouse, F. (1999). Relations between Teachers' Approaches to Teaching and Students' Approaches to Learning. Higher Education, 37(1), 57-70.

44. Usher, R., \& Edwards, R. (2007). Lifelong Learning: Signs, Discourses, Practices. Springer.

45. Vallejo, C., \& Dooly, M. (2013). Early School Leavers and Social Disadvantage in Spain: from books to bricks and vice-versa. European Journal of Education, 48(3), 390404. 